\title{
Anaesthesia for Caesarean Section in a Patient with Lumbar Syringomyelia
}

\author{
Lakshmi Jayaraman ${ }^{1}$, Nitin Sethi ${ }^{2}$, Jayashree Sood ${ }^{3}$
}

\begin{abstract}
Summary: Jayaraman L, Sethi N, Sood J - Anaesthesia For Caesarean Section in a Patient with Lumbar Syringomyelia.
Background and objectives: Syringomyelia is a rare neurological condition characterized by the presence of an expansive cystic cavity in the spinal cord, resulting in several neurologic manifestations. The objective of the present report was to address the safety of general anesthesia in this group of patients.
\end{abstract}

Case report: This is a 28-year old primipara with lumbar syringomyelia scheduled for lower segment cesarean section (LSC). Surgery was performed under general anesthesia without complications. General anesthesia was chosen for this patient to avoid manipulation of the subarachnoid space during neuraxial anesthesia, which could cause changes in intracranial pressure or worsening neurological symptoms. We used rocuronium considering that it avoids rising in cerebrospinal fluid pressure and hyperkalemia that can be seen with succinylcholine.

Conclusions: General anesthesia can be safely used in patients with syringomyelia. Care should be taken to prevent increase in intracranial pressure and neuromuscular blockade should be monitored.

Keywords: Syringomyelia; Anesthesia, General; Cesarean Section; Neuromuscular Nondepolarizing Agents, rocuronium.

[Rev Bras Anestesiol 2011;61(4): 469-473] @Elsevier Editora Ltda.

\section{INTRODUCTION}

Syringomyelia, an unusual neurological condition, is characterized by the presence of an expanding cystic cavity within the spinal cord resulting in neurological manifestations. The physiological changes during labor may aggravate neurological changes, such as brainstem herniation and spinal cord compression. Regional anesthesia is a relative contraindication due to the possibility of worsening of neurological symptoms.

\section{CASE REPORT}

A 28 year-old $(72 \mathrm{~kg}$ ) primigravida diagnosed with lumbar syringomyelia presented to us for lower segment cesarean section (LSCS). The patient had history of progressive weakness of the left leg for the past 6 years, with rapid progression in the past year, associated with decreased touch sensation in the left leg. Neurological examination revealed marked

Received from the Department of Anesthesiology, Pain, Perioperative Medicine, Sir Ganga Ram Hospital , New Delhi, India.

1. DA; DNB; Senior consultant, Department of Anaesthesia; MAX Superspeciality Hospital; Saket, New Delhi, India

2. DNB; Associate Consultant, Department of Anaesthesiology, Pain \& Perioperative Medicine: Sir Ganga Ram Hospital, New Delhi, India

3. MD, FFARCA, PGDHHM; Senior Consultant \& Chairperson, Department of Anaesthesiology, Pain \& Perioperative Medicine; Sir Ganga Ram Hospital; New Delhi, India

Submitted on October 26, 2010

Approved on December 22, 1010.

Correspondence to:

Dr. Nitin Sethi

DNB House No. 646, Sector -15

Faridabad

121007 - Haryana, India.

E-mail: nitinsethi77@yahoo.co.in muscle atrophy of the left leg. There was a decreased sensation to pain and temperature corresponding to $\mathrm{L}_{2}-\mathrm{L}_{5}$ dermatome. The patient had a limping gait because of calf muscle atrophy. She developed calf muscle pain in the left leg during pregnancy. There was no cranial nerve, bowel, or bladder involvement. MRI revealed cystic degeneration of lumbar spinal cord (D12-L5 region) (Figure 1). Elective LSCS was planned for this patient as she had cephalopelvic disproportion with breech presentation.

Upon arrival at the operating theater, monitoring with pulse oximetry, ECG, and noninvasive blood pressure was started. A peripheral neuromuscular monitor was attached to the right wrist. The patient was pre-oxygenated for 3 minutes. Anes-

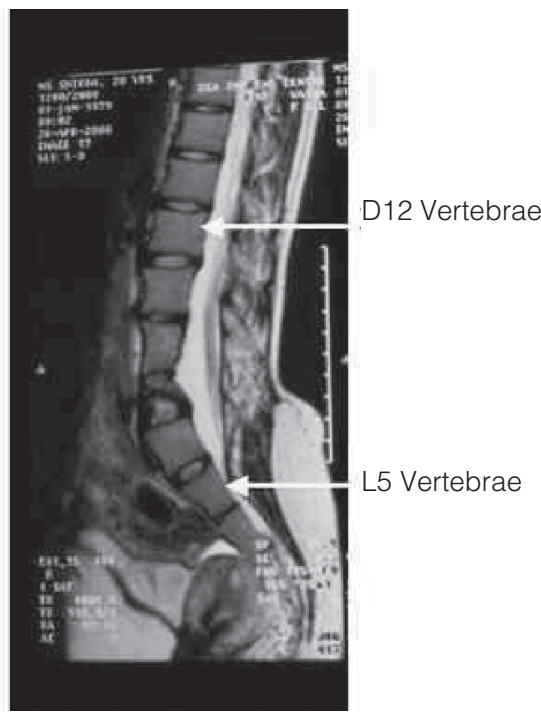

Figure 1 - MRI Lumbosacral Spine.

Syrinx extending from D12 to L5 vertebrae. 
thesia was induced with thiopentone sodium $250 \mathrm{mg} \mathrm{IV}$ and muscle relaxation achieved with rocuronium bromide $50 \mathrm{mg}$ IV. Tracheal intubation was done with a cuffed endotracheal tube 60 seconds after muscle relaxant administration.

Anesthesia was maintained with $\mathrm{O}_{2}, \mathrm{~N}_{2} \mathrm{O}$, and sevoflurane. The patient remained hemodynamically stable throughout the procedure. At the end of surgery, the trachea was extubated after reversing the effect of neuromuscular blockade with neostigmine $2.5 \mathrm{mg}$ and glycopyrrolate $0.5 \mathrm{mg}$. The postoperative course was uneventful with no neurological deterioration. The patient was discharged on the $5^{\text {th }}$ postoperative day.

\section{DISCUSSION}

We report the safe use of general anesthesia for cesarean section in a patient with syringomyelia. There are only few reports on pregnancies complicated with syringomyelia, and the optimal anesthetic management of such cases has not yet been established.

Syringomyelia is characterized by the presence of a expanding, fluid-filled cystic cavity or syrinx within the spinal cord. Ollivies d' Angers (1827) coined the term syringomyelia ${ }^{1}$ from two Greek words meaning "channel" and "marroin". It has a prevalence of 8.4 per 100,000 2. Syringomyelia has been divided into two groups, communicating with the cerebrospinal fluid pathways (communicating syringomyelia) and those that do not communicate (non-communicating) ${ }^{3}$.

The communicating form is the most common. There is a persisting continuity between syrinx and subarachnoid space and its cerebrospinal fluid (CSF). Most cases of communicating syringomyelia are linked to congenital or acquired anomalies involving the foramen magnum, of which the Chiari type I anomaly is the commonest ${ }^{4}$. The resultant syrinx typically arises in the lower cervical or upper thoracic region; expansion is characteristically very gradual, initially into the anterior and lateral cord. Extension upwards into the medulla often occurs (syringobulbia), whereas involvement of the lumbar region of the spinal cord is uncommon.

In the non-communicating form the syrinx may develop anywhere in the cord. Factors involved on the onset of cavitation may include hematoma, ischaemia, venous obstruction, shearing stress with mechanical disruption and proteinaceous fluid secretion. Non-communicating form may also be due to an idiopathic cause.

Our patient had a non-communicating syringomyelia due to an idiopathic cause involving the lumbar region, whose incidence is rare.

A classic case of syringomyelia presents with assymmetrical loss of pain and temperature sensation in the upper limb (lateral spinothalamic tracts), lower motor neuron signs in the hands (anterior horn cells), and upper motor neuron signs in the lower limbs (corticospinal tracts). The presence of posterior column signs usually means advanced disease ${ }^{4}$. Trophic changes may be striking, particularly the development of gross osteoarthropathy (Charcot's joints). Cardiac autonomic neuropathy is more likely when there is a coexisting syringomyelia ${ }^{6}$.

Associated abnormalities may have specific implications for anesthesia - kyphoscoliosis, cervical ribs, fused cervical vertebrae (Klippel-Feil syndrome), hydrocephalus, and spina bifida ${ }^{4,5,7}$, in addition to presence of a Chiari type I anomaly or other foramen magnum disorders ${ }^{8}$.

The possible problems that can arise during the anesthetic management of these patients are:

1. Permanent damage to the spinal cord due to increased intracranial pressure.

2. Abnormalities of autonomic nervous system, such as tachyarrhythmias, widely fluctuating arterial pressure, sudden cardiac or respiratory arrest.

3. Ventilation-perfusion abnormalities due to complications, such as deformities of the vertebral column or vocal cord paralysis.

4. Trophic lesions in the skin may limit venous access.

5. Disorganized joints and fixed flexion deformities require careful positioning.

6. Abnormal reaction to a muscle relaxant in patients with myotonic atrophy 4,9 .

Roelofse et al. ${ }^{9}$ chose general anaesthesia for their patient with syringomyelia using gallamine for tracheal intubation. The authors recommended general anesthesia for medicolegal reasons rather than a neuraxial blockade. Murayama et al. ${ }^{10}$ have also reported the use of general anesthesia, using vecuronium for tracheal intubation. However, Nel et al. ${ }^{11}$ used epidural anesthesia for anesthetic management of their patient with syringomyelia. .

We used rocuronium, a non-depolarizing muscle relaxant, even though its use has not been reported for anesthetic management of patient with syringomyelia. The advantage of rocuronium is that it avoids rise in CSF pressure and hyperkalemia ${ }^{11}$, which may occur with succinylcholine. Moreover, rocuronium has rapid onset action and may be used for rapid sequence induction; this circumvents the need for a priming dose. We administered rocuronium in minimal doses guided by neuromuscular blockade monitor, as increased sensitivity to non-depolarizing neuromuscular agents has been demonstrated in patients with syringomyelia 9 .

To conclude, general anesthesia may be safely used in a patient with syringomyelia in order to avoid increased intracranial pressure. We recommend the use of rocuronium instead of succinylcholine for tracheal intubation in patients with syringomyelia. 


\section{REFERÊNCIAS / REFERENCES}

01. Madsen PW, Yezierski RP, Holets VR - Syringomyelia: clinical observations and experimental studies. J Neurotrauma, 1994;11:241-254.

02. Brewis M, Poskanzer DC, Rolland C et al. - Neurological disease in an English city. Acta Neurol Scand, 1966;42(suppl):1-89.

03. Williams $B-$ The distending force in the production of "communicating syringomyelia". Lancet, 1969;2:189-193.

04. Walton JN - Brain's Disease of the Nervous System, $9^{\text {th }}$ Ed, Oxford, Oxford University Press, 1985;412-416.

05. Williams B - On the pathogenesis of syringomyelia: a review. J R Soc Med, 1980;73:798-806.

06. Nogues MA, Newman PK, Male VJ et al. - Cardiovascular reflexes in syringomyelia. Brain, 1982;105:835-849.

07. Mcllroy WJ, Richardson JC - Syringomyelia: a clinical review of 75 cases. Can Med Assoc J, 1965;93:731-734.

08. Semple DA, McClure JH, Wallace EM - Arnold-Chiari malformation in pregnancy. Anaesthesia, 1996;51:580-582.

09. Roelofse JA, Shipton EA, Nell AC - Anaesthesia for caesarean section in a patient with syringomyelia. A case report. S Afr Med J, 1984;65:736-737.

10. Murayama K, Mamiya K, Nozaki K et al. - Cesarean section in a patient with syringomyelia. Can J Anaest, h 2001;48:474-477.

11. Nel MR, Robson V, Robinson PN - Extradural anaesthesia for caesarean section in a patient with syringomyelia and Chiari type I anomaly. Br J Anaesth, 1998;80:512-515.
Resumen: Jayaraman L, Sethi N, Sood J - Anestesia para Cesárea en Paciente con Siringomielia Lumbar.

Justificativa y objetivos: La Siringomielia es una condición neurológica poco frecuente y caracterizada por la presencia de una cavidad cística expansiva en la médula espinal, resultando en varias manifestaciones neurológicas. El objetivo de este artículo es destacar la seguridad de la anestesia general en ese grupo de pacientes.

Relato del Caso: Primípara de 28 años, con diagnóstico de siringomielia lumbar, que fue programada para la cirugía de cesárea (CC). La cirugía fue realizada bajo anestesia general, sin complicaciones. La anestesia general fue elegida, en el caso de esa paciente, para evitar cualquier manipulación del espacio subaracnoide durante el bloqueo del neuro eje central, lo que podría conllevar a alteraciones de la presión intracraneana o al empeoramiento de los síntomas neurológicos. Se usó el rocuronio, al considerar que evita el aumento de la presión en el líquido cefalorraquídeo y la hipercalemia, que puede ser vista con la succinilcolina.

Conclusiones: La anestesia general puede ser usada con seguridad en pacientes portadores de siringomielia. Debemos tomar precauciones para evitar el aumento de la presión intracraneana y el bloqueo neuromuscular debe ser monitorizado.

Descriptores: ANESTESIA: General; BLOQUEO MUSCULAR; ClRUGÍA: Cesárea; ENFERMEDADES: Neurológica, siringomielia. 